Studia i materiały z dziedzictwa kulturowego Torunia i regionu, t. 1: STARE I NOWE DZIEDZICTWO TORUNIA,

Toruń 2013

http://dx.doi.org/10.12775/SiMzDzKTiR_T1.2013.014

Joanna Kucharzewska (IZIK UMK, TORUŃ)

\title{
Pałac Fengerów przy ul. Mostowej w Toruniu w świetle nowych badań zabytkoznawczo-konserwatorskich
}

Pałac/Dom Fengerów ${ }^{1}$ - zespół składający się z kamienicy frontowej, oficyn bocznych i spichlerza - jako reprezentatywny przykład zabudowy ulicy Mostowej (ul. Mostowa 14) funkcjonuje w świadomości historyków i konserwatorów jako cenny przykład zabudowy mieszkaniowej Torunia co najmniej od kilkudziesięciu lat, o czym świadczą zachowane w archiwum wytyczne Gwido Chmarzyńskiego², czy w końcu dość wczesny (1963 r.) wpis do rejestru zabytków (il. 2-5). Pomimo to obiekt był jedynie wymieniany w ogólnych pracach dotyczących kamienic toruńskich ${ }^{3}$ i nie powstała jak dotąd osobna monografia jemu poświęcona, być może głównie z tego powodu, iż nie było możliwości wykonania badań, potwierdzających wyjątkowość tego zespołu w skali Torunia. Niniejszy artykuł jest podsumowaniem wyników badań zabytkoznawczo-konserwatorskich, prowadzonych w 2009 roku w obrębie spichlerza oraz w 2010 roku w kamienicy wraz z oficynami ${ }^{4}$.

$1 \mathrm{~W}$ publikacjach z okresu dwudziestolecia międzywojennego stosowano wymiennie określenie „dom Fengera” (np. Reinhard HEUER, Das Merkwürdigste in, bey und um Thorn, Berlin 1925, s. 23) i „pałac Fengera“ (np. Gwido CHMARZYŃSKI, Sztuka w Toruniu. Zarys dziejów, Toruń 1934, s. 53). W publikacjach powojennych konsekwentnie używano określenia „pałac”: np. Eugeniusz GĄSIOROWSKI, Toruń - przewodnik po mieście, Warszawa 1965, s. 88; Bogusław MANSFELD, Toruń i okolice, Warszawa 1977, s.64; Zbigniew NAWROCKI, Toruńska starówka, Gdańsk 1982, s. 31; Ryszard SUDZIŃSKI, Toruń. Portret miasta, Warszawa 1988, s.58 itp. Mimo funkcjonowania w toruńskiej nomenklaturze takich określeń, jak np. „Dom Eskenów”, w przypadku obiektu zlokalizowanego przy ul. Mostowej 14 uprawnione jest użycie terminu „pałac”, dla podkreślenia formy budynku z XVIII wieku, który G. Chmarzyński scharakteryzował jako „formę nową, dotąd co do swych wymiarów niespotykaną” i przyrównał ją do pałacu Meisnera - CHMARZYŃSKI 1934, s. 53-54. Natomiast należy mieć świadomość, że obiekt wywodzi się z typowego średniowiecznego domu-składu, co wyjaśnia niniejszy artykuł.

2 Archiwum Państwowe Toruń, Akta miasta Torunia (dalej: AP Toruń, AmT), sygn. G 2779, k. 203; szczegółowe przytoczenie wytycznych na końcu artykułu.

3 Eugeniusz GĄSIOROWSKI, Toruńska kamienica mieszczańska, „Acta Universitatis Nicolai Copernici”, Zabytkoznawstwo i Konserwatorstwo 1966, z. 1, s. 79; Jan TAJCHMAN, Przemiany funkcjonalne toruńskiego domu mieszczańskiego w czasach nowożytnych, „Kwartalnik Architektury i Urbanistyki”, t. 30, 1985, z. 2, s. 122.

4 Joanna KUCHARZEWSKA, Piotr DĄBROWSKI, Dokumentacja konserwatorska: Rozwarstwienia chronologiczne murów budynku spichlerza przy ul. Podmurnej 13 w Toruniu, [kps] Toruń 2009, Archiwum Miejskiego Konserwatora Zabytków w Toruniu sygn. 4283; Joanna KUCHARZEWSKA, Piotr DĄBROWSKI, Elżbieta ROGOZIŃSKA, Dokumentacja konserwatorska: Badania architektoniczne i konserwatorskie w Pałacu Fengerów przy 
Okres pełnego rozkwitu ul. Mostowej przypadł na wiek XV, co wiązało się bezpośrednio z dynamicznym rozwojem Przedmieścia Portowego nad Wisłą, przebudową Bramy Przewoźnej (Mostowej) dokonaną przez Hansa Gotlanda w 1432 roku a wreszcie - z budową stałego mostu przez mistrza Postila z Budziszyna w latach 1497-15005. Rozbudowa infrastruktury na nabrzeżu wiślanym w XV wieku wzmocniła rolę komunikacyjną ulicy Mostowej, na której znajdowało się wówczas trzydzieści osiem samodzielnych działek, z czego dziesięć posiadało zaplecze na ulicy Podmurnej ${ }^{6}$. Jak wskazują pierwsze dane źródłowe, w miejscu dzisiejszego budynku frontowego pod nr 14 istniały dwie niezależne kamienice ${ }^{7}$. Nazwiska właścicieli działek wzmiankowane są już w końcu XIV wieku . Około 1460 roku dwie sąsiednie działki znalazły się w rękach jednego właściciela Joachima Czirenberga, ale analiza kolejnych zmian własnościowych i parcelacyjnych wskazuje, że dopiero w 1510 roku, kiedy teren był własnością Apolonii Kober, funkcjonował jeden okazały budynek frontowy 9 .

Okres średniowiecza. Sposób zabudowy działki w okresie średniowiecza pozostaje w wielu kwestiach niewyjaśniony, ale odnalezione w trakcie badań gotyckie fragmenty dostarczają danych, potwierdzających istnienie dwóch domów-składów. Nie odnaleziono zwartych części średniowiecznej fasady, a jedynie fragmenty fundamentu kamiennego, który został wtórnie wykorzystany podczas wymiany elewacji frontowej w latach 40 . XVIII wieku. W pełni gotycka na poziomie piwnicy jest za to ściana tylna (wschodnia), o jednolitych cechach strukturalnych na całej długości (wątek wendyjski, podobna spoina, fundament kamienny), która świadczy o tym, że kamienice budowane były jeśli nie w tym samym - to zapewne w zbliżonym czasie (il. 1.1). Potwierdzeniem istnienia pierwotnie dwóch kamienic jest częściowo zachowana ściana graniczna w wątku wendyjskim (il. 1.2). Kamienice były podobnej szerokości.

Kamienica południowa zachowała średniowieczną ścianę od strony ul. Ciasnej do wysokości II piętra (il. 1.3). Pomimo niezbyt dużej głębokości była dwutraktowa, co potwierdzają relikty ściany międzytraktowej na poziomie piwnicy i parteru (il. 1.4). Wielka sień kamieni-

ul. Mostowej 14 w Toruniu, t. 1, t. 2, [kps] Toruń 2010, Archiwum Miejskiego Konserwatora Zabytków w Toruniu, sygn. 4371.

5 Zenon Hubert NOWAK, W okresie państwa krzyżackiego, [w:] Historia Torunia, t.1: W czasach średniowiecza (do 1454), red. M. BISKUP, Toruń 1999, s. 282-283; Marian BISKUP, Terytorium, ludność, władze miejskie i ich finanse (1466-1548), [w:] Historia Torunia, t. 2, cz 1: U schyłku średniowiecza i w początkach odrodzenia (1454-1548), red. M. BISKUP, Toruń 1992, s. 71.

6 Krzysztof MIKULSKI, Przestrzeń i społeczeństwo Torunia od końca XIV do początku XVIII wieku, Toruń 1999, s. 333 .

7 AP Toruń, kat. II, dz. III, t. 69 (Schoßbuch von der Altstadt und deren Vorstädten 1394); AP Toruń, kat. II, dz. III, t. 70 (Restanten-Verzeichniss am Umlegeschoß der Altstadt 1396-98); AP Toruń, kat. II, dz. III, t. 76 (Zinsabrechnungsbuch der Kämerei anfangend 1454); AP Toruń, kat. I, nr 889 (1428), nr 866 (1435).

8 Krzysztof MIKULSKI, Właściciele i funkcje działek w kwartale świętojańskim od końca XIV do początku XIX wieku. Blok S, [kps] Toruń 1998, Archiwum Miejskiego Konserwatora Zabytków w Toruniu, sygn. 1837A, s. 2-5 Autor podaje, że w 1394 roku właścicielem działki południowej był Henricus Ronaw, z dopisanym Jacobem Megelicz, zaś północnej - rodzina Bollandów (w 1398 r. wymieniony kupiec Peter Bolland). W 1460 r. obydwie działki były własnością Joachima Czirenberga. W 1498 r. działki znów rozdzielono. W 1507 r. Apolonia Kober odziedziczyła kamienicę południową po zmarłym mężu Nicolasie i w 1510 r. dokupiła sąsiednią działkę północną, scalając kamienice i ten stan utrzymano w wiekach następnych.

9 TAMŻE, s. 4. 
cy południowej o wysokości około $480 \mathrm{~cm}$ dekorowana była wnęką o uskowo opracowanych krawędziach, w której dnie znajdowało się odcinkowo zwieńczone okno, doświetlające wnętrze od strony ul. Ciasnej (il. 1.5). Takie samo rozwiązanie istniało w trakcie tylnym, $\mathrm{z}$ tym, że dziś sfazowane krawędzie wnęki gotyckiej stanowią ościeża szerokiego otworu okiennego wprowadzonego w XIX wieku (il. 1.6).

Okres samodzielnego funkcjonowania tej stosunkowo niewielkiej kamienicy jest nieznany. Przylegająca do niej od wschodu oficyna powstała w drugim, być może niezbyt odległym, etapie budowlanym. Na granicy budynków przez całą wysokość elewacji południowej czytelny jest szew w typie strzępiów (il. 1.7). Oficynę wymurowano w wątku gotyckim. W celu skomunikowania kamienicy i oficyny na poziomie piwnic wykorzystano wnękę (il. 1.8), którą przekształcono na otwór drzwiowy (zmieniony powtórnie w XVII w.), na poziomie parteru oryginalna szerokość drzwi jest nadal zachowana (il. 1.9). W oficynie znajdowały się drzwi na podwórko, a obok nich okno, o którym dziś świadczy zaledwie sfazowane ościeże (il. 1.10). Na południowej ścianie oficyny (od ul. Ciasnej) na parterze w trakcie badań odnaleziono dwie średniowieczne wnęki (il. 1.11). Jedna (wschodnia) została w XVIII wieku zamurowana, a następnie w XIX wieku jej część przekształcono na szafę ścienną, poprzez wybranie wypełnienia i pogłębienie (czyli skucie średniowiecznego dna wnęki). Druga wnęka (zachodnia) o sfazowanych krawędziach, zwieńczona łukiem odcinkowym, jest zachowana w całości. Badania warstw malarskich potwierdziły, iż była polichromowana. Na obecnym, sondażowym etapie można potwierdzić występowanie wici roślinnej na ościeżu wnęki.

W przypadku kamienicy północnej istnieje również wiele dowodów, potwierdzających jej średniowieczne pochodzenie. Jak już zostało wspomniane wcześniej - w piwnicy znajduje się średniowieczna ściana tylna na fundamencie kamiennym (il. 1.1), natomiast ściana frontowa została wymieniona podczas XVIII-wiecznej przebudowy. Obwodowa ściana północna zapewne także jest średniowieczna (il. 1.12), jednak jej rozpoznanie utrudnia obecność nowożytnego oblicowania, stanowiącego podparcie dla sklepienia $\mathrm{z}$ tego czasu (XVII w.). Jej istnienie potwierdza jednak widoczny fundament kamienny oraz fakt, że ściana w wątku wendyjskim zachowała się na całej wysokości kamienicy (korona muru średniowiecznego sięga do połowy wysokości dzisiejszego poddasza budynku frontowego).

Badania wykazały, że kamienica północna była dłuższa od wcześniej omawianej, za to równa z sąsiednią kamienicą pod numerem 16 (również gotycką). Kraniec wschodni ściany gotyckiej jest doskonale wyeksponowany ponad dachem dzisiejszej oficyny północnej w postaci pasa strzępi. Nasuwa to wniosek, że kamienica północna od początku była planowana jako obiekt, zajmujący pełną głębokość działki frontowej, a dzisiejsza ściana tylna jest tak naprawdę ścianą międzytraktową. Pod dzisiejszą oficyną północną, a także pod częścią podwórka, można się zatem spodziewać tylnego traktu piwnic gotyckich. Tę tezę, uprawdopodobnioną zamurowanym otworem komunikacyjnym na poziomie piwnicy (il. 1.13), mogą ostatecznie potwierdzić badania archeologiczne.

Kamienica miała reprezentacyjną sień o wysokości nie mniejszej niż 4,7 m. Nie odnaleziono śladów gniazd belek stopowych nad sienią, co wskazywać może, że były one układane na osi wschód-zachód, czyli opierały się na ścianach frontowej i międzytraktowej, które zo- 
stały usunięte w okresie nowożytnym. Minimalną wysokość sieni potwierdza zachowana częściowo wnęka (dziś $130 \mathrm{~cm}$ nad podłogą I piętra). Zachodnia strona wnęki została rozebrana już w okresie średniowiecza, w czasie przemurowań o charakterze naprawczym (il. 1.14).

Drugim argumentem na występowanie bardzo wysokiej - może nawet ponad 5-metrowej wysokości - sieni jest poziom dolnej krawędzi średniowiecznego kominka (obecnie na linii sufitu nad I piętrem). Kominek - z dobrze zachowanymi krawędziami bocznymi oraz częściowo rozebranym zwieńczeniem w formie odcinkowego łuku - dziś znajduje się na poziomie II piętra, a pierwotnie mieścił się w izbie nad sienią (il. 1.15).

Analiza ściany północnej na wysokości obecnego pierwszego piętra pozwoliła także na zlokalizowanie w tylnym trakcie kominka, poświadczającego przypuszczenia o zróżnicowanej wysokości traktów, typowej dla układu funkcjonalnego domu-składu (il. 1.16).

W trakcie badań, nie odnaleziono (za wyjątkiem piwnicy) śladów średniowiecznej ściany międzytraktowej, jednak z dużym prawdopodobieństwem można przyjąć, że jej lokalizacja pokrywała się z linią ściany tylnej budynku frontowego (pochodzącej z XVIII w.).

W 1505 roku działkę południową wraz z kamienicą i oficyną zakupił Nicolas Kober kupiec i rajca staromiejski. Dwa lata później (po jego śmierci) nieruchomość odziedziczyła jego żona Apollonia, która w 1510 roku dokupiła część północną ${ }^{10}$. Od tego momentu nastąpiło scalenie działek. Jak wyglądała owa średniowieczna modernizacja, na czym polegało połączenie funkcjonalno-przestrzenne wnętrza i estetyczne fasady pozostanie zapewne nierozstrzygniętą kwestią, gdyż w wyniku późniejszych zmian budowlanych usunięto zarówno ścianę graniczną między kamienicami oraz ich - wspólną jak można się domyślać z zapisów źródłowych - fasadę. Krzysztof Mikulski analizując funkcje działek średniowiecznych przy ob. ul. Mostowej 14 wylicza, że do końca XV wieku w źródłach pojawiają się określenia 2 Hofestethe, 2 Hoferethe, ale już od 1510 roku występują zapiski Hoffstelle lub po prostu $H a u \beta^{11}$, co w pewien sposób uzasadnia przypuszczenia o wspólnej fasadzie domu.

Okres nowożytny to kolejny etap budowlany, który znacząco wpłynął na kształt zabudowy działki. Gruntowne przekształcenia budowlane zaszły na początku XVII wieku, kiedy właścicielami posesji byli burmistrz Jacob Rüdiger (zmarły w 1609 roku) oraz jego syn, kupiec i rajca Michel Rüdiger (zmarły w 1619 roku) ${ }^{12}$. Zmiany rozpoczęli od wzniesienia okazałego 4-kondygnacyjnego spichlerza na tyłach działki (il. 5). Elewacje budynku zostały pokryte tynkami z charakterystycznym rysunkiem, imitującym boniowanie - relikty tej dekoracji zachowały się w osłoniętych partiach ścian, np. na styku z oficynami. Badania dendrochronologiczne prowadzone w oparciu o materiał pobrany z belek stropowych i

10 TAMŻE, s. 4.

11 TAMŻE, s. 5.

12 Stefan Cackowski przyrównuje rodzinę Rüdigerów pod względem majętności i zasług dla miasta $\mathrm{z}$ takimi rodzinami jak: Eskenowie, Krügerowie czy Mochingerowie. Wskazuje jednocześnie, że szczególną postacią ówczesnego życia był Henryk Stroband - humanista, umiejętnie wykorzystujący własne zdolności intelektualne i ekonomiczne dla rozwoju miasta - por. Stefan CACKOWSKI, W czasach Rzeczpospolitej szlacheckiej, [w:] Toruń dawny i dzisiejszy. Zarys dziejów, red. M. BISKUP, Warszawa - Poznań - Torun 1983, s. 180. Nie bez znaczenia dla formy budynków oficynowych Rüdigerów był wybudowany w latach 1596-1601 z inicjatywy Strobanda budynek gimnazjum akademickiego (tzw. Ekonomia) przy ul. Piekary, który mógł być dla nich inspiracją. 
więźby dachowej potwierdziły, że ścinka drzew, z których później je wykonano, musiała nastąpić na przełomie 1606-1607 $\mathrm{roku}^{13}$. Zatem teza o powstaniu obiektu w $1607 \mathrm{roku}$, formułowana w oparciu o dane archiwalne, znalazła potwierdzenie w badaniach materiałowych.

W kolejnym etapie rodzina Rüdigerów przystąpiła do wzniesienia bocznych oficyn, tworząc zachowany do dziś kształt zabudowy działki (il. 4). Okres nowych inwestycji potraktowano także jako dogodny moment dla znacznej modernizacji budynków już istniejących. Zmianami dotknięta była przede wszystkim część północna. W nowej koncepcji Rüdigerów kamienica północna była krótsza, sięgała pierwotnej szerokości przedniego traktu. Na poziomie piwnicy założono dwie równoległe kolebki w układzie poprzecznym. Nową piwnicę skomunikowano ze średniowieczną (południową) za pomocą otworu drzwiowego, przewidzianego już na etapie wznoszenia kolebki, w której wypracowano lunetę sklepienną (il. 1.17).

Eliminacja tylnego traktu kamienicy północnej uwolniła znaczny fragment podwórka i pozwoliła na zmiany w średniowiecznej oficynie południowej, które oznaczały wyburzenie znacznych partii ścian wschodniej i północnej. Nad piwnicą założono sklepienie kolebkowe z lunetami nad otworami komunikacyjnymi (il. 1.18). Pod względem formalnym sklepienie było analogiczne z tym w piwnicy północnej. Na średniowiecznych ścianach piwnicy wybudowano dwie narożne ściany nowożytne (północną i wschodnią) i przewiązano je z reliktowo zachowanymi pasami średniowiecznego muru (il. 1.19). Nowy fragment oficyny południowej na poziomie parteru i I piętra artykułowany był dużymi otworami okiennymi o sfazowanych krawędziach, na których zachowała się jeszcze oryginalna warstwa malarska (kolor karminowo-czerwony i ciemnoszara linia wzdłuż krawędzi).

Nowożytne oficyny (północna i południowo-wschodnia), które zamknęły boki podwórka, utrzymane były w jednakowej, charakterystycznej dla tego czasu manierze stylowej. Były jednopiętrowe; elewacjom nadano rytmiczną artykulację i zwieńczono wydatnymi gzymsami identycznymi z tymi, które zastosowano w budynku spichlerza. Otwory okienne parteru o sfazowanych ościeżach zamknięte były łukami koszowymi. Otwory okienne piętra miały wykrój prostokątny a ich szerokość, pomimo późniejszych przekształceń wnętrza i zmian stolarki okiennej, została zachowana - o czym świadczą ślady pierwotnej polichromii (ten sam kolor karminowo-czerwony).

Nowe oficyny boczne zostały skomunikowane $\mathrm{z}$ budynkiem frontowym (zarówno na poziomie parteru, jak i piętra) i podobnie jak on, pełniły funkcje mieszkalne. Izby oficyn były modnie dekorowane - dziś przekonuje o tym odnaleziony strop w skrajnym, zachodnim pomieszczeniu oficyny północnej, z dekoracją malarską w formie wici roślinnych na jasnym tle (il. 1.20). Górne kondygnacje budynku frontowego nadal traktowano jako powierzchnię magazynową.

Druga przebudowa nowożytna łączy się z okresem, kiedy właścicielem działki została rodzina Fengerów. Krzysztof Mikulski podaje, że bogaty kupiec i bankier Johann Fenger stał

13 Aleksander KONIECZNY, Badania dendrochronologiczne belek stropowych i więźby dachowej w budynku przy ul. Podmurnej 13 w Toruniu, [kps] Toruń 2009, Archiwum Miejskiego Konserwatora Zabytków w Toruniu, [b. sygn.]. 
się właścicielem parceli w 1744 roku $^{14}$ i zapewne wtedy przystąpił do gruntownego remontu. Większość badaczy jest jednak skłonna przesuwać datę rozpoczęcia przebudowy na 1742 rok $^{15}$. Na taką datę wskazywał także Jerzy Fryderyk Steiner, który na jednej ze swoich rycin dokładnie przedstawił fasadę nowego pałacu miejskiego wraz z inskrypcją ponad głównym portalem Anno. Soli Deo Gloria. $1742^{16}$. Sporne dwa lata, w obliczu zmian budowlanych i funkcjonalnych, jakich dokonano w I połowie XVIII wieku, nie stanowią tu istoty sprawy.

Budynek otrzymał nową, reprezentacyjną fasadę (7-osiową, 4-kondygnacyjną), przez co nazywany był Pałacem Fengera (il. 2), choć pod względem funkcjonalnym wywodził się z typowej kamienicy mieszczańskiej. Główne wejście, umieszczone pośrodku centralnego ryzalitu, poprzedzone było podestem z dekoracyjną kratą. Parter był boniowany, przerywany otworami okiennymi z kutymi kratami. Na skrajnych osiach parteru znajdowały się dwa zejścia do piwnic. Otwory okienne wyższych kondygnacji ujęte były stiukowymi opaskami z uszakami. Przestrzenie między oknami wypełniały geometryczne płyciny, w partiach podokiennych, na co drugiej osi, znajdowała się dekoracja floralna a w górnej partii pilastrów festony. Środkowa zryzalitowana część w partii dachu przechodziła w facjatę zwieńczoną segmentowym naczółkiem dekorowanym rzeźbą figuralną. Symetrycznie względem niej w połaci dachowej widniały jeszcze dwie lukarny ${ }^{17}$.

Jak wspomniano wyżej, z czasów średniowiecznych pozostawiono ściany w piwnicy, z wyjątkiem fasady (na której skrajach wprowadzono szyje piwniczne). Na wyższych kondygnacjach zachowano ściany na granicy działki - od ulicy Ciasnej (do wysokości drugiego piętra) oraz przeciwległą ścianę na granicy z sąsiednią kamienicą pod numerem 16 . Średniowieczne podziały wewnętrzne zostały niemal doszczętnie rozebrane, zamiast nich pojawiły się nowe, o konstrukcji szkieletowej, dostosowane do ówczesnych wymogów funkcjonalnych.

Funkcje mieszkalne wpisane były w dwie kondygnacje (parter i pierwsze piętro), podczas gdy dwie wyższe służyły celom magazynowym. Po przekroczeniu wejścia otwierała się wysoka sień ze schodami (o balustradzie brusowej polichromowanej) przy tylnej ścianie, prowadzącymi na wyższą kondygnację (il. 1.21). Po obu stronach sieni znajdowały się izby, a w południowo-wschodnim narożniku kuchnia z wysokim kapturem, zajmującym całą wysokość pierwszego piętra. Za kuchnią, w części oficyny, wydzielono wąskie pomieszczenie

14 MIKULSKI 1998, s. 4.

15 CHMARZYŃSKI 1934, s. 53, NAWROCKI 1982, s. 31; TAJCHMAN 1985, s. 124; Heuer zanotował, że Jan Fenger zmarł w styczniu 1747 roku i mógł się cieszyć swoją budowlą zaledwie 5 lat (Er starb im Januar 1747, hat sich kaum fünf Jahre lang seines stattlichen Hauses freuen könen - HEUER 1925, s. 23.)

16 Georg Friedrich STEINER, Das neuerbaute Gebäude S.N.W. H. Fengers in der Brücken-Straße - na podstawie: Toruń i miasta Ziemi Chełmińskiej na rysunkach Jerzego Fryderyka Steinera z pierwszej połowy XVIII wieku (tzw. Album Steinera), red. M. BISKUP, Toruń 1998, s. 126 i 222.

17 Opis w oparciu o rycinę J. F. Steinera - TAMżE, s. 126. G. Chmarzyński w 1934 roku fasadę opisywał w następujący sposób: Wysunięty ryzalit środkowy z wejściem i szczytem dachowym stwarza oś centralną. Obok której grupują się w odważnych dystansach okna na cofniętych ścianach. Opracowanie detali architektoniczno-zdobniczych wskazuje na genezę południowo-niemiecką z jej odmianq saską („nach Leipziger Art”). - CHMARZYŃSKI 1934, s. 53-54. 
(spiżarnię), potwierdzone w trakcie badań śladem ścianki działowej, rozebranej w XIX wieku (il. 1.22). Pozostałą część oficyny skomunikowano bezpośrednio z sienią, poprzez otwór drzwiowy pod schodami.

Schody dekorowane balustradą brusową prowadziły na galeryjkę, skąd istniała możliwość przejścia do niewielkiego pomieszczenia południowego w trakcie przednim, oraz izby i alkowy (kammer) w części północnej budynku głównego. Z poziomu galeryjki wchodziło się po dwóch stopniach do pomieszczeń oficyny. W oficynie strop nad parterem został $\mathrm{w}$ trakcie przebudowy obniżony. Zmiana ta wymusiła zamurowanie siedemnastowiecznych okien i zastąpienie ich nowymi o wykrojach zbliżonych do kwadratu (il. 1.23). Nowy strop założono również nad pierwszym piętrem, przemurowując przy okazji koronę murów obwodowych i wprowadzając gzyms koronujący analogiczny do tego, jakim zwieńczono budynek frontowy. W trakcie badań odnaleziono ślad po dawnym stropie z okresu Rüdigerów (na 1 piętrze oficyny) w postaci zamurowanego gniazda $\mathrm{z}$ pierwotną dekoracją malarską $\mathrm{w}$ formie czarnej opaski wokół niego. W tym samym pomieszczeniu, na pierwszym piętrze oficyny, wydzielono dwa pomieszczenia za pomocą ścianki szkieletowej z umieszczonymi centralnie szerokimi dwuskrzydłowymi drzwiami rokokowymi (il. 1.24).

Dekoracja domu wynikała z ówczesnej mody (il. 7). Na parterze budynku frontowego, na przeciwległych ścianach wielkiej sieni odnaleziono analogiczną dekorację malarską w geometrycznych podziałach wpisano wicie roślinne (il. 1.25). Dokładny opis formalny na obecnym etapie odkrywek jest niemożliwy. Niezbyt jasny pozostaje sposób opracowania pozostałych ścianek szkieletowych. Odkrywki świadczą o tym, że tynkowane były jedynie pola wypełnień, natomiast słupy i belki pozostawały surowe, względnie posiadały proste, monochromatyczne opracowanie malarskie. Prawdopodobnie duże powierzchnie ścian szkieletowych posiadały jakiś niezachowany sposób zewnętrznego wykończenia, np. kołtryny lub boazerie. Ta ostatnia dekoracja została odnaleziona w północno-wschodnim narożu parteru oraz w południowym pomieszczeniu na I piętrze oficyny południowo-zachodniej (il. 1.26).

W całym budynku frontowym założono nowe jednolite stropy belkowe o sfazowanych krawędziach. Stropy w pomieszczeniach sąsiadujących z wielką sienią na poziomie piętra były eksponowane jako belkowe, polichromowane. Najbardziej dekoracyjnym wnętrzem była zapewne izdebka na pierwszym piętrze, na co wskazuje opracowanie malarskie stropu - belki pokryto ornamentem wstęgowo-cęgowym, a deski ornamentem floralnym, pojawiają się girlandy oraz wazy z owocami (il. 1.27). Ponad galerią i korytarzem na piętrze stropy odeskowano na zakładkę deskami o profilowanych krawędziach, które otrzymały jednobarwne wykończenie malarskie. W pozostałych pomieszczeniach (w tym nad sienią) zostały odeskowane surowymi deskami i przeklejone płótnem, które zagruntowano i pomalowano (może pokryto dekoracjami malarskimi), niestety żadne z płócien nie zachowało się do naszych czasów. Dowodem tego rozwiązania dekoracyjnego są jedynie strzępki płócien odnalezione w narożnikach. Dopełnieniem wystroju były drzwi ramowo-płycinowe o falistym wykroju krawędzi oraz intarsje.

Dekoracje stosowano tylko w pomieszczeniach o funkcjach mieszkalnych. Powyżej pierwszego piętra znajdowały pomieszczenia o charakterze magazynowym. Wejście na kon- 
dygnacje magazynowe znajdowało się w narożniku północno-wschodnim pierwszego piętra budynku frontowego, co zostało potwierdzone negatywowym śladem na ścianie po nieistniejących już dziś schodach (il. 1.28).

W dwóch równoległych oficynach bocznych nieznacznie skorygowano układ pomieszczeń, wprowadzając nowe ściany działowe oraz zmieniono kształt otworów okiennych, maskując jednocześnie łuki otworów siedemnastowiecznych. Późnobarokowa forma obiektu i dyspozycja wnętrza dotrwały do 1835 roku, tj. do czasu przekształcenia „pałacu” w kamienicę czynszową.

Po śmierci Johana Fengera w 1747 roku właścicielką domu została wdowa Anna Elżbieta Nogge (p.v. Zerneke ${ }^{18}$ ) wraz z synem Jacobem. Jakub Fenger od 1758 roku piastował funkcję ławnika podmiejskiego, a od 1767 roku rajcy. Był eksporterem zboża i handlarzem wełny a nade wszystko zdolnym finansistą. Siedziba rodziny tzw. Palais Fenger, była jednym z ośrodków życia towarzyskiego miasta ${ }^{19}$. Po śmierci Jakuba Fengera w 1798 roku budynek na Mostowej odziedziczyła jego jedyna córka Ludwika Skarbek ${ }^{20}$, a w 1818 roku jej najstarszy syn Fryderyk Florian Skarbek ${ }^{21}$. Z racji, iż Skarbek był ojcem chrzestnym Fryderyka Chopina, ten w trakcie swoich letnich wakacji w Szafarni odwiedził go w Toruniu w 1825 roku. Majątek przy ul. Mostowej 14 w Toruniu należał do Fryderyka Skarbka do 1835 roku.

W „Taksie Specyalnej...” sporządzonej w 1813 roku wymienia się budynek główny - murowany o 4 piętrach, dwa domy poboczne „na tej samej stronie” i dom poboczny na lewej stronie o 2 piętrach ${ }^{22}$. Kolejne informacje źródłowe o zabudowie na działce pochodzą z 1833 roku, kiedy to przygotowywano wycenę budynku i określono jego stan przed sprzedażą kolejnemu właścicielowi. Z dokumentu wiadomo, że na działce znajdował się budynek główny,

18 Jerzy Wojtowicz podaje, że żoną Johana Fengera była Anna Elżbieta Nogge, wdowa po ławniku Janie Zerneke - Jerzy WOJTOWICZ, Fryderyk Florian Skarbek (1792-1866), [w:] Wybitni ludzie dawnego Torunia, red. M. BISKUP, Warszawa - Poznań - Toruń 1982, s. 161; Krzysztof Mikulski z kolei podaje, że żoną była Anna Maria z domu Bremel - MIKULSKI 1998, s. 4.

19 WOJTOWICZ 1982, s. 161.

20 W 1791 roku o rękę jego jedynej córki Ludwiki starał się - z poparciem samego króla Stanisława Augusta - Kasper Skarbek. Ludwika wniosła w posagu znaczny majątek (m.in. była właścicielką majątku w Żelazowej Woli), a jej ojciec zapłacił wszystkie długi zięcia i dokupił dodatkowe dobra ziemskie. Po kilku latach małżeństwa Kasper Skarbek doprowadził majątek rodziny na skraj bankructwa, a sam ratował się przed wierzycielami ucieczką za granicę. Aby ocalić choć część majątku (m.in. kamienicę w Toruniu) Ludwika Skarbkowa wszczęła w 1804 roku postępowanie rozwodowe. Po spłacie długów wyjechała z Torunia i wraz z piątką nieletnich dzieci osiadła w Żelazowej Woli - WOJTOWICZ 1982, s. 162.

21 Najstarszy syn Ludwiki - Fryderyk Florian Skarbek urodził się w Toruniu w 1792 roku (dokładna data dzienna nie jest pewna - 15 luty lub 23 luty). Pierwsze lata dzieciństwa spędził w rodzinnym domu w Toruniu, w którym gromadzili się przedstawiciele miejskiej elity, następne lata - w Żelazowej Woli pod opieką Mikołaja Chopina. Dalszą naukę pobierał w Królewskim Gimnazjum w Warszawie pod okiem rektora Samuela Bogumiła Lindego (w latach 1805-08) - swego dawnego nauczyciela $\mathrm{z}$ Torunia. W latach 1809-11 przebywał na studiach w Paryżu. Był także znanym ekonomistą, powieściopisarzem, historykiem (napisał m.in. Dzieje Księstwa Warszawskiego w 1860) oraz działaczem społecznym i politycznym. W jednej ze swych powieści, zatytułowanej „Pamiętniki Seglasa”, rodzinnemu miastu poświęcił cały rozdział („Karnawał w Toruniu”), w który wplótł wątki biograficzne WOJTOWICZ 1982, passim.

22 Kwatera Staromiejska „S” w obrębie ulic Podmurna, Szeroka, Mostowa, Ciasna, Archiwum Miejskiego Konserwatora Zabytków w Toruniu, sygn. 2180/1. 
trzy domy boczne, jeden budynek tylny, studnia, „szauer” i stajnia ${ }^{23}$. W 1835 roku działkę zakupił Friedrich Wilhelm Beuth - kupiec z Lubicza. Sporządzony wówczas opis nieruchomości podawał te same budynki z dopiskiem „alles in guten Stande” (wszystko w dobrym stanie $)^{24}$. Do opisu załączono rysunki inwentaryzacyjne ${ }^{25}$ (il. 8). Po śmierci Friedricha Wilhelma Beutha, w 1857 roku, nieruchomość odziedziczyła wdowa Mathilde Beuth z domu Meyer i syn Georg ${ }^{26}$. W tym czasie parter budynku frontowego przystosowywany był do funkcji usługowych, co łączyło się z odseparowaniem komunikacji dla lokatorów. Zrezygnowano z przestrzeni wysokiej, fengerowskiej sieni, ale zachowano jej ściany boczne (il. 1.25). Na linii wejścia wykonano wąski korytarz, który tworzyły północna ściana dawnej sieni i dobudowana w odległości około $160 \mathrm{~cm}$ ściana równoległa. Korytarz - prowadzący na klatkę schodową i do wyjścia na podwórko - umożliwiał swobodną komunikację lokatorów mieszkających na wyższych kondygnacjach i w oficynach, do których z kolei wejście znajdowało się od strony wewnętrznego podwórka. Symetrycznie względem środkowego korytarza zaplanowano sklepy, składające się z dwóch pomieszczeń - części usługowej (Laden) i zaplecza (Stube). Do każdego ze sklepów przebito oddzielne wejścia wprost z ulicy ${ }^{27}$. Pierwszy wykonano sklep od strony południowej, a w 1869 roku Mathilde Beuth dokonała adaptacji części północnejej ${ }^{28}$

Rezygnacja z osiemnastowiecznej sieni pozwoliła także na efektywniejsze wykorzystanie powierzchni I piętra, na którym wygospodarowano dwa osobne mieszkania. Z klatki schodowej wchodziło się także do mieszkania usytuowanego w oficynie południowo-wschodniej. Podczas tej przebudowy usunięto schody magazynowe przy ścianie północnej budynku (il. 1.28), natomiast główną klatkę schodową przedłużono do poziomu drugiego piętra. Dobudowany fragment schodów wyróżnia się odmienną balustradą - szczeblinową, kratową. Dzięki temu funkcje mieszkalne można było wpisać także na poziomie drugiego piętra w budynku głównym. W północnym mieszkaniu zapewne już wówczas wprowadzono wewnętrzne schody komunikujące z trzecim piętrem, o czym świadczy zastosowanie podobnej balustrady szczeblinowej, kratowej. Natomiast nie ma potwierdzenia w archiwaliach tego, że główna klatka schodowa została w tym samym czasie przedłużona do trzeciego piętra. Według badań in situ najbardziej prawdopodobne wydaje się, że istniały jakieś prowizoryczne schody drabiniaste, a dopiero w kolejnym etapie (w końcu XIX lub na początku XX w.) wprowadzono wygodniejsze schody zaopatrzone w odmienną (niż te użyte wcześniej) balustradę ze szczeblin pionowych (il. 9). W czasie, kiedy właścicielami była rodzina Beuth (od 1835 r. do lat 70. XIX w.) spichlerz od strony ul. Podmurnej nadal pełnił funkcje magazynowe. Natomiast dwa równoległe budynki oficyn wykorzystywano dla celów mieszkalnych

23 AP Toruń, AmT, sygn. F 27, k. 26.

24 AP Toruń, AmT, sygn. F 27, k. 10-15.

25 AP Toruń, AmT, sygn. G 2779, k. 1.

26 AP Toruń, AmT, sygn. F 27, k. 178.

27 AP Toruń, AmT G 2779, k. 10, Zeichnung zur Anbringung zweier neuen Schaufenster nebst Ladenthür in den Wohnhauße Brückenstrasse 20 der Kaufmann Frau Wittwe Beuth gehörig, 10. III. 1869.

28 AP Toruń, AmT, sygn. G 2779, k. 8. 
i gospodarczych (warsztatowych, magazynowych) - w nich komunikacja odbywała się niezależnie.

W latach 70. XIX wieku posesję nabyli David Gliksmann (Glücksmann) i jego żona Rosalia $^{29}$. W 1878 roku wdowa Gliksmann zaadaptowała pomieszczenia w oficynie północnej (Seitengebäude links) na destylatornię - zdemontowała wcześniejszy strop wraz z okapem kominowym i zamontowała nowy strop odcinkowy na belkach stalowych. Piętro przeznaczono na leżakowanie win i skład butelek wódki ${ }^{30}$.

W latach 90. XIX wieku rozszerzono zakres prac adaptacyjnych na parterze budynku głównego. Wówczas sklep funkcjonował tylko w części południowej, w północnej zaś urządzono wyszynk z dwoma pokojami gościnnymi. Do głównej sali wchodziło się bezpośrednio z ulicy (ale istniało też wejście z korytarza), w tyle znajdowała się kuchnia, a od północy wąski pokój skomunikowany z drugim w oficynie ${ }^{31}$. Pozwolenie na prowadzenie działalności gospodarczej wymagało zgody magistratu. Tę burmistrz Stachowitz wydał 4 listopada 1897 roku. Wyszynk przy ulicy Mostowej 14 funkcjonował pod szyldem Piplow i Domański $^{32}$. Prawdopodobnie ze względu na charakter działalności restauratorskiej utrzymano w tylnej części oficyny północnej destylatornię (na rysunkach określane jako Werkstatträume). W oficynie południowej, zgodnie z adnotacją na planie z 1897 roku pozostawiono funkcje mieszkalne ${ }^{33}$. Oficyna tylna nadal widniała w dokumentach jako spichlerz (il. 10).

Na początku XX wieku nastąpiło rozdzielenie posesji pomiędzy dwóch właścicieli - jeden przejął kamienicę wraz z oficynami (B. Hożakowski), drugi spichlerz (kupiec Fridrich Radmann i jego żona Emilia) ${ }^{34}$. Z tego czasu (1902 r.) pochodził śmiały, choć niezrealizowany pomysł zadaszenia części posesji szklanym dachem, według projektu mistrza murarskiego Gustawa Plehwe ${ }^{35}$. Realne zmiany natomiast zaszły w użytkowaniu południowego sklepu, który około 1903 roku przestał funkcjonować. Jego dwa pomieszczenia wraz z dwoma w oficynie południowo-zachodniej oraz jednym w oficynie południowo-wschodniej tworzyły duże mieszkanie, do którego wchodziło się od strony podwórka (il. 10). Stan ten zapewne trwał dość krótko, ze względu na korzystne usytuowanie pomieszczeń w budynku głównym, bezpośrednio skomunikowanych z ulicą, nadających się do prowadzenia sklepu ${ }^{36}$. W spichlerzu na parterze wprowadzono lekkie przepierzenia i urządzono skład (Speicher),

29 AP Toruń, AmT F 27.

30 AP Toruń, AmT G 2779, k. 14.

31 Projekt adaptacji na wyszynk (autorstwa mistrza murarskiego J. Górnego) złożono 13 października $1897 \mathrm{r}$. AP Toruń, AmT, sygn. G 2779, k. 60.

32 AP Toruń, AmT G 2779, k. 66.

33 AP Toruń AmT G 2779, k. 60.

34 W 1901 r. starano się o pozwolenie na wywieszenie dwóch szyldów: Wielkopolska wytwórnia win owocowych M. Szarszewski oraz Destylatornia specjalnych likierów $i$ wódek Kałkuj i Sp., co wyraźnie wskazywało na utrzymanie produkcji alkoholi w oficynie. - AP Toruń, AmT, sygn. G 2779, k. 107.

35 AP Toruń, AmT G 2779, k. 107.

36 Zapewne jeszcze w 1. poł. XX wieku powrócono do układu trzech niezależnych pomieszczeń: sklep od frontu, mieszkanie w oficynie południowo-zachodniej z wejściem od strony podwórka oraz niewielkie mieszkanie w oficynie południowo-wschodniej także z osobnym wejściem od podwórka. 
warsztat (Werkstätte) i zaplecze (Kammer), pozostawiając oczywiście przejazd (Einfahrt).

W okresie dwudziestolecia międzywojennego nie zachodziły większe zmiany budowla$n^{37}$, choć nie obyło się bez zmian własnościowych. Nowym właścicielem kamienicy z oficynami został Julian Wykrzykowski, który w 1927 roku dokupił jeszcze - wystawiony na sprzedaż w ramach „przymusowego przetargu” z powodu zadłużenia - budynek spichlerza, ponownie scalając nieruchomości w rękach jednego właściciela ${ }^{38}$.

We wrześniu 1935 roku posesję kupił profesor gimnazjum toruńskiego Stanisław Jan Szyc $^{39}$. Na swoje mieszkanie wybrał północny fragment kamienicy frontowej na drugim i trzecim piętrze. Poziomy - jak opisano wyżej - połączone były wewnętrznymi schodami. W tym czasie, w pozostałej części trzeciego piętra funkcjonowały już dwa niewielkie mieszkania, do których można się było dostać dzięki przedłużeniu głównej klatki schodowej (z balustradą o prostych szczeblinach pionowych). W 1937 roku S. J. Szyc uzyskał pozwolenie na dobudowę balkonu, na środkowej osi fasady ${ }^{40}$.

Po zakończeniu drugiej wojny światowej S. J. Szyc wynajął spichlerz „Fabryce szyldów, stempli i wyrobów metalowych”, której właścicielem od 1920 roku był Henryk Rausch. Firma ta działała w czasie II wojny, po sąsiedzku w budynku przy ul. Podmurnej 15. Od 1943 roku korzystała także z oficyny północnej na działce Mostowa 14, o czym świadczył m.in. otwór komunikujący dwie sąsiednie parcele. Kiedy po wojnie zwiększyły się zamówienia, firma wynajęła jeszcze budynek spichlerza. W 1948 roku, w ramach upaństwowienia prywatnych przedsiębiorstw, fabryka Rauscha została przejęta przez Pomorską Dyrekcję Metalowego i Elektrotechnicznego Przemysłu Miejscowego w Bydgoszczy ${ }^{41}$.

W drugiej połowie lat 70. XX wieku spichlerz stał się własnością Zrzeszenia Właścicieli i Zarządców Nieruchomościami, a od 2005 roku - właścicieli prywatnych. Tymczasem kamienica wraz z oficynami aż do 2007 roku pozostawała w rękach rodziny Szyców. Pomieszczenia na parterze (a także częściowo w piwnicy) nadal pełniły funkcje handlowo-usługowe a pozostałe lokale przeznaczone były na funkcje mieszkalne.

Podczas kwerendy archiwalnej, dotyczącej obiektu, natrafiono na interesujące dokumenty z lat 30. XX wieku, odzwierciedlające metodykę pracy konserwatorskiej i ówczesne poglą-

37 W dokumentach odnotowano drobne naprawy kominów (1925), kanalizacji, odświeżanie elewacji oraz starania o zgodę na zawieszenie szyldów reklamowych - np. w 1921 r. Klara Skarbaszewska reklamowała swoją działalności jako Owocarnia-interes specjalny, a w 1929 r. Władysław i Czesław Rutkowscy Hurtownię skór i przyborów obuwniczych. W 1926 r. komisja sanitarna stwierdziła fatalny stan budynków gospodarczych (chlewnia, pralnia) umieszczonych w podwórzu, wykonanych z „pruskiego muru”. 7 sierpnia 1926 roku w raporcie policji budowlanej odnotowano - z właściwą dla owych czasów skrupulatnością - że pralnia się zawaliła przysypując bieliznę lokatorki Jaworskiej - AP Toruń, AmT, sygn. G 2779, k. 169.

Oględziny spichlerza dokonane przez komisję sanitarną w kwietniu 1929 r. wykazały nienajlepszy stan tynków na elewacjach, nieszczelność instalacji deszczowej, wadliwie działającą instalację sanitarną oraz uszkodzenie bramy od strony podwórza W odpowiedzi na zarzuty komisji właściciel poinformował o wykonaniu tynkowania elewacji w 1925 i 1928 r. przez mistrzów budowlanych Ignacego Jarockiego oraz Franciszka Pachula (tynkowano wówczas elewację zachodnią i wschodnią) - AP Toruń, AmT, sygn. G 3381.

38 AP Toruń, AmT, sygn. G 3381.

39 AP Toruń, AmT G 2779, k. 312.

40 AP Toruń, AmT G 2779, k. 342, 343.

41 AP Toruń, AmT, sygn. G 2779, k. 353. 
dy konserwatorskie na sprawę ochrony zabytków. Fragmenty tych dokumentów autorstwa Gwidona Chmarzyńskiego - Wojewódzkiego Konserwatora Zabytków - warte są przytoczenia jako zwieńczenie niniejszego artykułu ${ }^{42}$.

... odnowienie rzeczonej ściany [zewnętrznej spichlerza] można przeprowadzić $w$ dwojaki sposób tj. albo tynkując całość wapnem hydraulicznym $z$ umieszczeniem boniowania - jak to jeszcze na fragmentach jest widoczne, albo można tynki zupetnie usunać, zostawiajac szczyt w surowej cegle. Wskazanym byłby sposób pierwszy ze względu na odnowienie otoczenia tej czesści ulicy.(... ${ }^{43}$. I dalej: Dom w Toruniu przy ul. Mostowej Nr 14 (...) został zbudowany w r. 1742 w stylu barokowym dla patrycjuszowskiej rodziny toruńskiej Fengerów. W domu tym urodził się sławny ekonomista polski hr. Skarbek, którego rodzina dziedziczyła dom po Fengerach. Dobra rycine fasady domu w pierwotnym jej wyglądzie pozostawit Steiner (...). Fasada domu (...) została krótko przed wojną ${ }^{44} w$ sposób niekulturalny odnowiona, przy czem usunięto charakterystyczne cechy ornamentacyjne z I poł. XVIII wieku. Nadto zmieniono układ zewnętrzny parteru tworzac obok wejścia głównego trzy nowe składy handlowe. Jako budynek o znacznej wartości historycznej dla miasta (pałac po-Skarbowski) i artystycznej (interesujacy i nieliczny okaz architektury późno-barokowej Torunia) winien on być otoczony szczególna opieka. Dlatego należy przede wszystkim dązyć do unormowania kwestji reklamowej fasady. (...) Reklamy winny być zredukowane do minimum, charakter ich musi być ujednostajniony, estetyczny i zastosowany do konstrukcji osi pionowych budynku, nie zaciemniajac jego linij. (...) [Firmy] winny wspólnie rozwiązać kwestję reklam tego domu, umieszczając ewentualnie jedynie reljefowy napis nad sklepami, niżej gzymsu. Należy unikać przede wszystkiem napisów kolorowych $i$ malowanych, nie licujących $z$ architektura budynku. (... ${ }^{45}$.

Niniejszy artykuł ma charakter przyczynkowy. Na obecnym etapie wiedzy na temat kamienicy pozostaje wiele kwestii nierozstrzygniętych. Potwierdzenie niektórych tez, postawionych w tekście, może nastąpić po badaniach archeologicznych oraz pogłębionych badaniach w trakcie prac remontowo-budowlanych. Kolejnym krokiem, decydującym o przyszłości tego niezwykle wartościowego obiektu, będącego świadectwem minionej patrycjuszowskiej świetności, byłby projekt budowlany, mogący uczytelnić najcenniejsze frag-

42 Fragment pochodzi z ekspertyzy sporządzonej przez G. Chmarzyńskiego 28 lutego 1931 r. na zlecenie Sądu Wojewódzkiego Pomorskiego w sprawie o niedopełnienie obowiązków przez właściciela posesji przy ul. Podmurnej 13/Mostowa 14 Juliana Wykrzykowskiego (AP Toruń, AmT G 2779, k. 223). W kwietniu 1929 r. Komisja Sanitarna stwierdziła zły stan tynków na elewacjach spichlerza przy ul. Podmurnej 13, nieszczelność instalacji deszczowej, wadliwie działającą instalację sanitarną oraz uszkodzenie bramy od strony podwórza (AP Toruń, AmT G 3381, k. 10). Właściciel pragnąc uniknąć kolejnych napraw elewacji (zwłaszcza nietynkowanej wcześniej elewacji południowej spichlerza) posłużył się argumentem dotyczącym zabytkowego charakteru obiektu i w czerwcu 1929 roku pisał do Komisji Sanitarnej: Zaznaczam, że dom podlega ochronie przez konserwatora (...). Pan konserwator $\dot{z} y c z y$ sobie, aby części zostające pod ochrona konserwatora utrzymały charakter starożytny (AP Toruń, AmT G 3381, k. 17). Wobec takiego argumentu Komisja Sanitarna początkowo odstąpiła od swoich żądań, ale ostatecznie sprawa zakończyła się wyrokiem Sądu Wojewódzkiego Pomorskiego z listopada 1930 roku, który nakazał J. Wykrzykowskiemu odnowienie elewacji spichlerza. Sąd uzasadniał wyrok ekspertyzą Gwidona Chmarzyńskiego - Wojewódzkiego Konserwatora Zabytków.

43 AP Toruń, AmT, sygn. G 3381, k. 67.

44 Zapis ten świadczy, że jeszcze w pierwszym dziesięcioleciu XX w. elewacja frontowa posiadała barokowy wystrój.

45 AP Toruń, AmT, sygn. G 2779, k. 203. 
menty struktury zabytkowej poprzez wpisanie nowej funkcji, respektującej kilkuwiekową tradycję tego miejsca.

\section{丵潦 嚓}

\section{Fenger Palace Mostowa street in Torun in light of the new conservation researches}

Fenger Palace - architectural ensemble consists of front apartment house, outbuilding side and granary at 14 Mostowa and 13 Podmurna street in Torun, it is interesting example of stylish stratification and functional changes, resulting from the determined fashion and needs the next users. The history of that place reaches up to XV century, with the development of the port wharf, construction of the Mostowa Gate and crossings through Vistula river the role of Mostowa street was increasing, fine tenements houses appeared. In the period of the Middle Ages on the current department with address 14 Mostowa street there were two gothic tenements: north, two-route, filling the full depth of the front plot, and south, which also had two-routes, but about the smaller depth what allowed for building the outbuilding in later time. The base of the department (today 13 Podmurna street) was filled with the building of the granary only in 1607. At that time the tenement house belonged to Rüdiger family. At the begging of XVII century appeared two parallel buildings of single-store annexes and a few building changes were implemented within front buildings (for example knocking down the back route of the north tenement, putting vaults on in the north basement). However functional major changes occurred in 1742, when a rich merchant and a banker purchased premises - Johann Fenger. Then the front building received the new, representative facade, decorated with the rich architectural details. Inside the house a high entrance hall was located, about walls drawn up in a way befitting a painter. By its, there were chambers and the kitchen. Residential functions were planned also on the first floor, above stores existed warehousing facilities. This state held out until 1835. In XIX century the building along with annexes was converted into the mulch-occupied house with the functional ground floor (shops). The granary didn't undergo the biggest changes for the entire period of its lasting, it was used as the storehouse, junk-shop or an outbuilding. At present none of these buildings are being used.

Translated by Agnieszka Szypczyn 


\section{SPIS ILUSTRACJI:}

1. Toruń, schemat faz budowlanych na działce Mostowa 14/Podmurna 13, oprac. J. Kucharzewska.

2. Toruń, fasada Pałacu Jana Fengera uwieczniona na rysunku w latach 40 . XVIII wieku przez Jerzego Fryderyka Steinera (wg: Toruń i miasta Ziemi Chełmińskiej na rysunkach Jerzego Fryderyka Steinera z pierwszej połowy XVIII wieku, red. M. Biskup, Toruń 1998, s. 126); Fasada - stan obecny, fot. J. Kucharzewska.

3. Toruń, Pałac Fengera, widok oficyny południowo-zachodniej i elewacji tylnej budynku frontowego, fot. J. Kucharzewska.

4. Toruń, Pałac Fengera, Widok oficyn bocznych (północnej i południowej) od strony podwórka, fot. J. Kucharzewska.

5. Toruń, Spichlerz przy ul. Podmurnej 13. Widok fasady, elewacji tylnej od strony podwórka, fragment wnętrza i zachowane relikty tynkarskiego boniowania, fot. J. Kucharzewska.

6. Toruń, zachowane wnęki wielkich sieni sąsiednich kamienic gotyckich - południowej i północnej. We wnęce od strony ul. Ciasnej wpisane okno. Wnęka kamienicy północnej z przemurowaniem naprawczym z okresu średniowiecznego, fot. J. Kucharzewska.

7. Toruń, Pałac Fengera, zachowane elementy dekoracji i wyposażenia: polichromowany strop w pomieszczeniu południowym na I piętrze, dekoracja ścianek wysokiej sieni, intarsja na drzwiach, boazeria w pomieszczeniu oficyny południowo-zachodniej, fot. J. Kucharzewska.

8. Inwentaryzacja budynków na działce Mostowa 14/Podmurna 13 w Toruniu sporządzona jako załącznik do umowy kupna posesji przez Friedricha Wilhelma Beutha 1 III 1835 roku. Na rysunku widoczny szkic zmian adaptacyjnych (czerwony kolor) pochodzący z 1878 roku, Archiwum Państwowe w Toruniu, Akta miasta Torunia, sygn. F 27, k. 10.

9. Toruń, Pałac Fengera, główna klatka schodowa w budynku frontowym. Odcinki schodów pochodzące $\mathrm{z}$ różnych etapów adaptacji na cele mieszkalne: odcinek z parteru na I piętro z balustradą brusową polichromowaną z 1742 roku; balustrada szczeblinowa, kratowa między I a II piętrem powstała w czasie adaptacji na kamienicę wielorodzinną po 1835 roku i odcinek schodów między II a III piętrem z balustradą szczeblinową pionową, fot. J. Kucharzewska.

10. Toruń, Pałac Fengera, rzut parteru z 1897 i 1903 roku, Archiwum Państwowe w Toruniu, Akta miasta Torunia, sygn. G 2779, k. 60 i k. 121. 

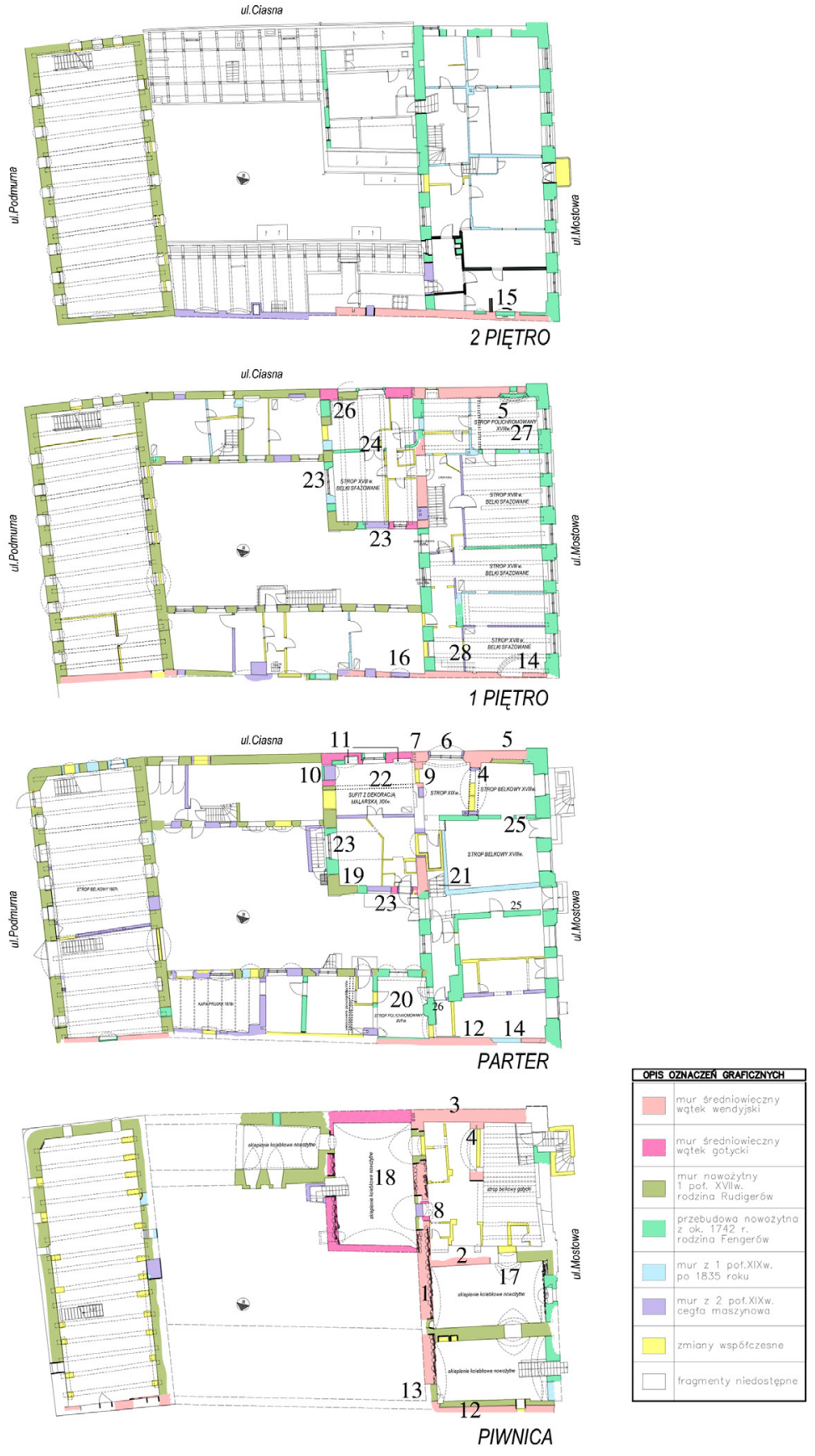

Il. 1 Toruń, schemat faz budowlanych na działce Mostowa 14/Podmurna 13, oprac. J. Kucharzewska 




Il. 2 Toruń, fasada Pałacu Jana Fengera uwieczniona na rysunku w latach 40. XVIII wieku przez Jerzego Fryderyka Steinera (wg: Toruń i miasta Ziemi Chełmińskiej na rysunkach Jerzego Fryderyka Steinera z pierwszej połowy XVIII wieku, red. M. Biskup, Toruń 1998, s. 126); Fasada - stan obecny, fot. J. Kucharzewska

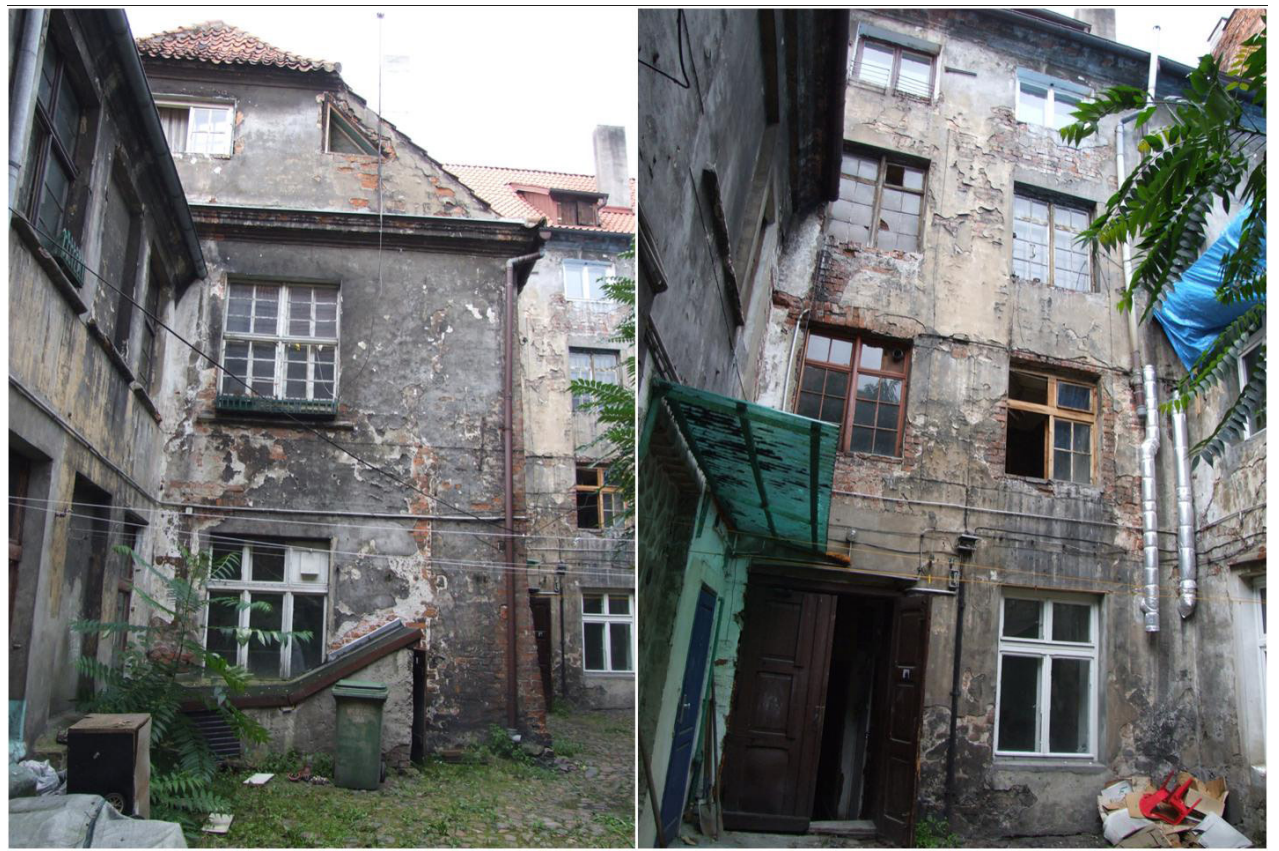

Il. 3 Toruń, Pałac Fengera, widok oficyny południowo-zachodniej i elewacji tylnej budynku frontowego, fot. J. Kucharzewska 


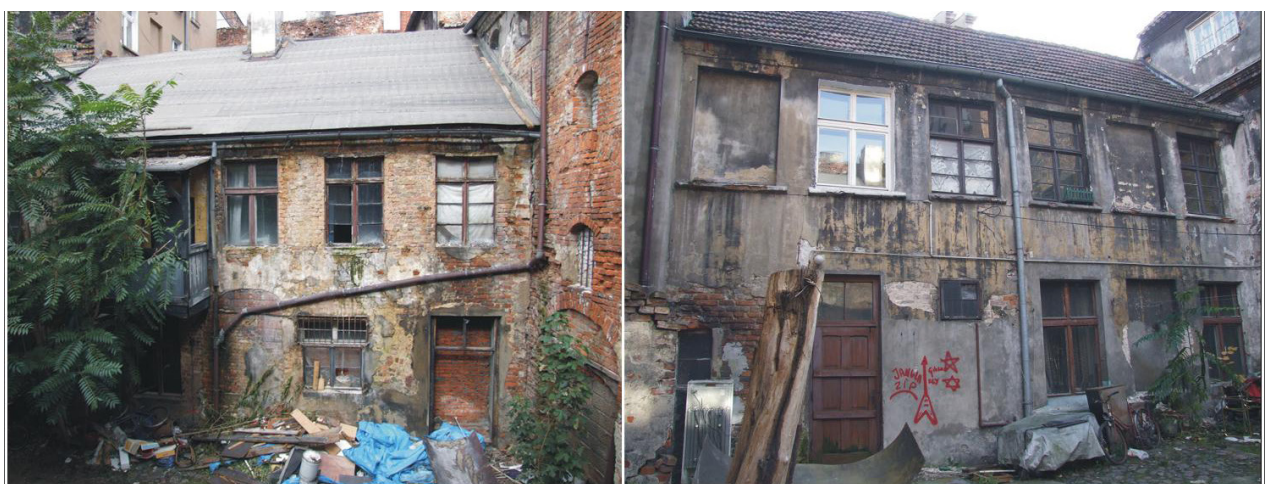

Il. 4 Toruń, Pałac Fengera, Widok oficyn bocznych (północnej i południowej) od strony podwórka, fot. J. Kucharzewska

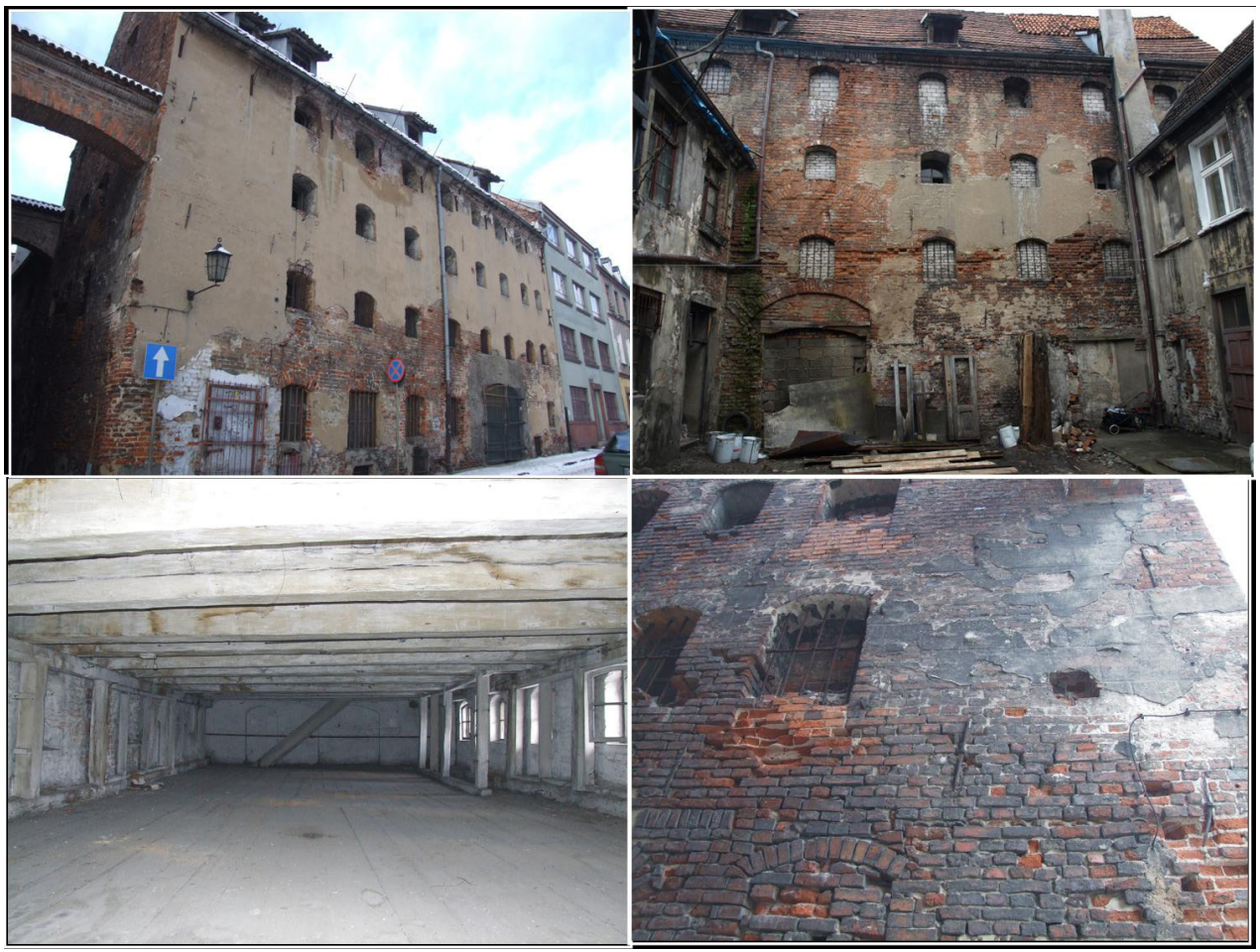

Il. 5 Toruń, spichlerz przy ul. Podmurnej 13. Widok fasady, elewacji tylnej od strony podwórka, fragment wnętrza i zachowane relikty tynkarskiego boniowania, fot. J. Kucharzewska 



Il. 6 Toruń, zachowane wnęki wielkich sieni sąsiednich kamienic gotyckich - południowej i północnej. We wnęce od strony ul. Ciasnej wpisane okno. Wnęka kamienicy północnej z przemurowaniem naprawczym z okresu średniowiecznego, fot. J. Kucharzewska

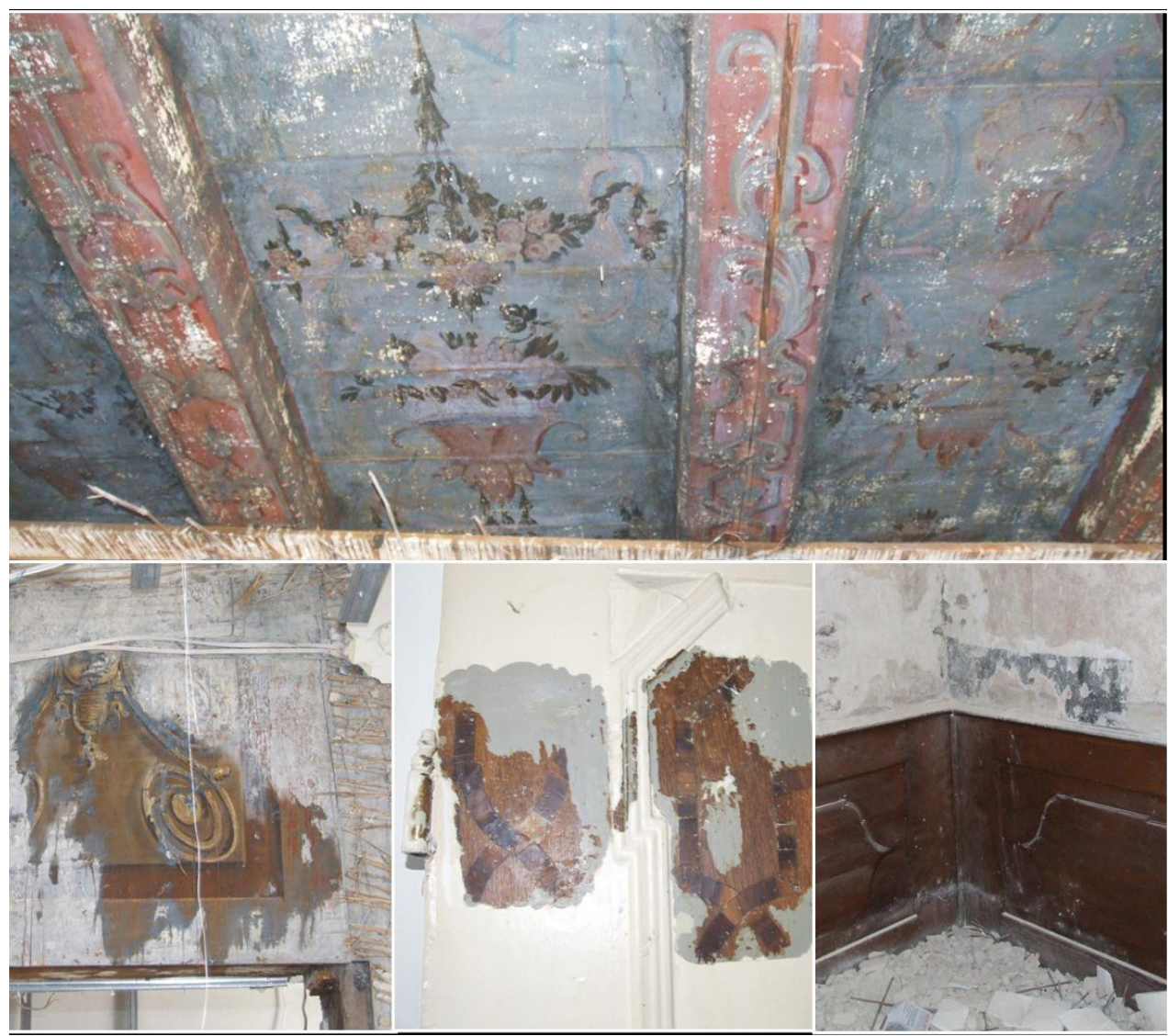

Il. 7 Toruń, Pałac Fengera, zachowane elementy dekoracji i wyposażenia: polichromowany strop w pomieszczeniu południowym na I piętrze, dekoracja ścianek wysokiej sieni, intarsja na drzwiach, boazeria w pomieszczeniu oficyny południowo-zachodniej, fot. J. Kucharzewska 


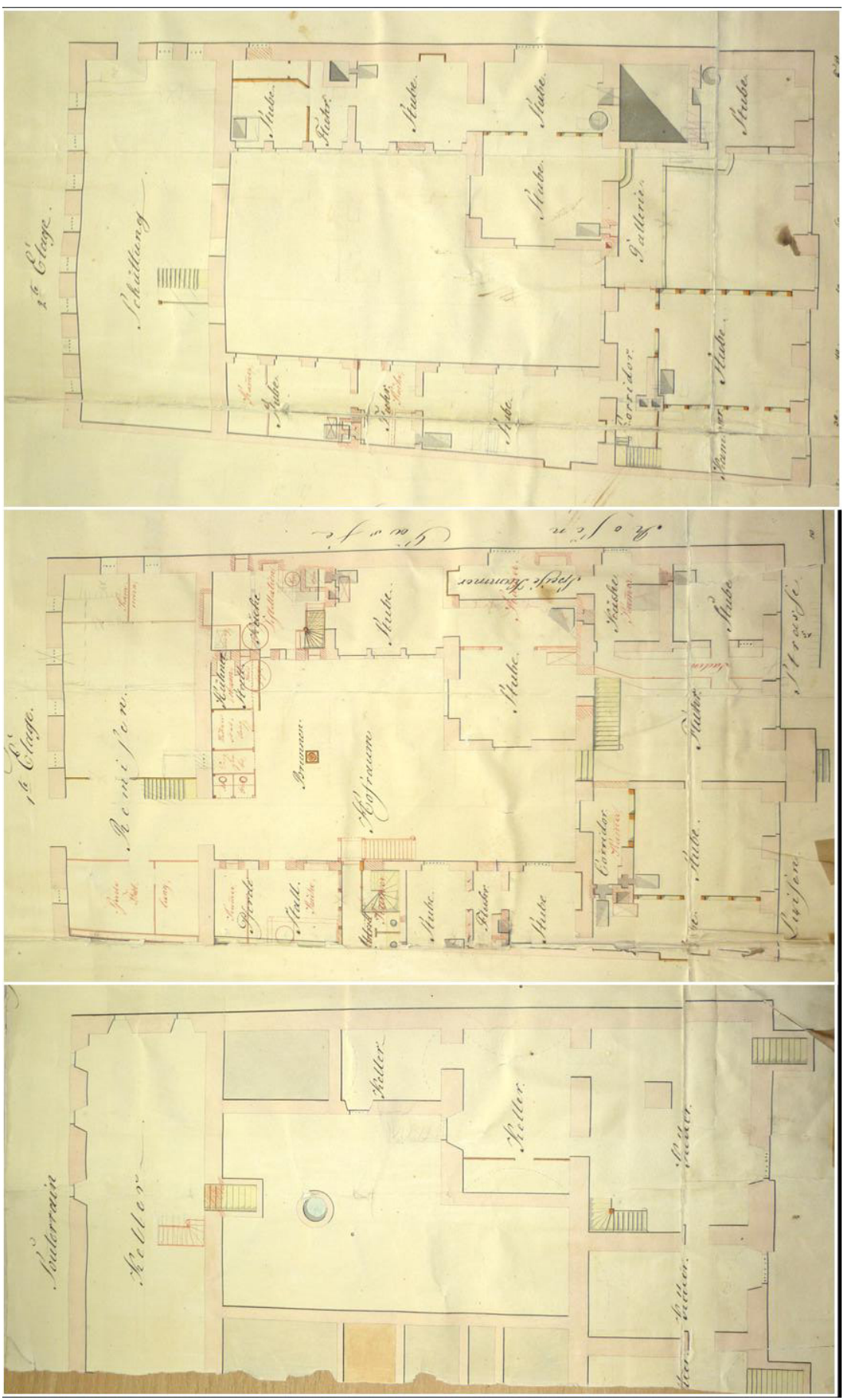

Il. 8 Inwentaryzacja budynków na działce Mostowa 14/Podmurna 13 w Toruniu sporządzona jako załącznik do umowy kupna posesji przez Friedricha Wilhelma Beutha 1 III 1835 roku. Na rysunku widoczny szkic zmian adaptacyjnych (czerwony kolor) pochodzący z 1878 roku, Archiwum Państwowe w Toruniu, Akta miasta Torunia, sygn. F 27, k. 10 

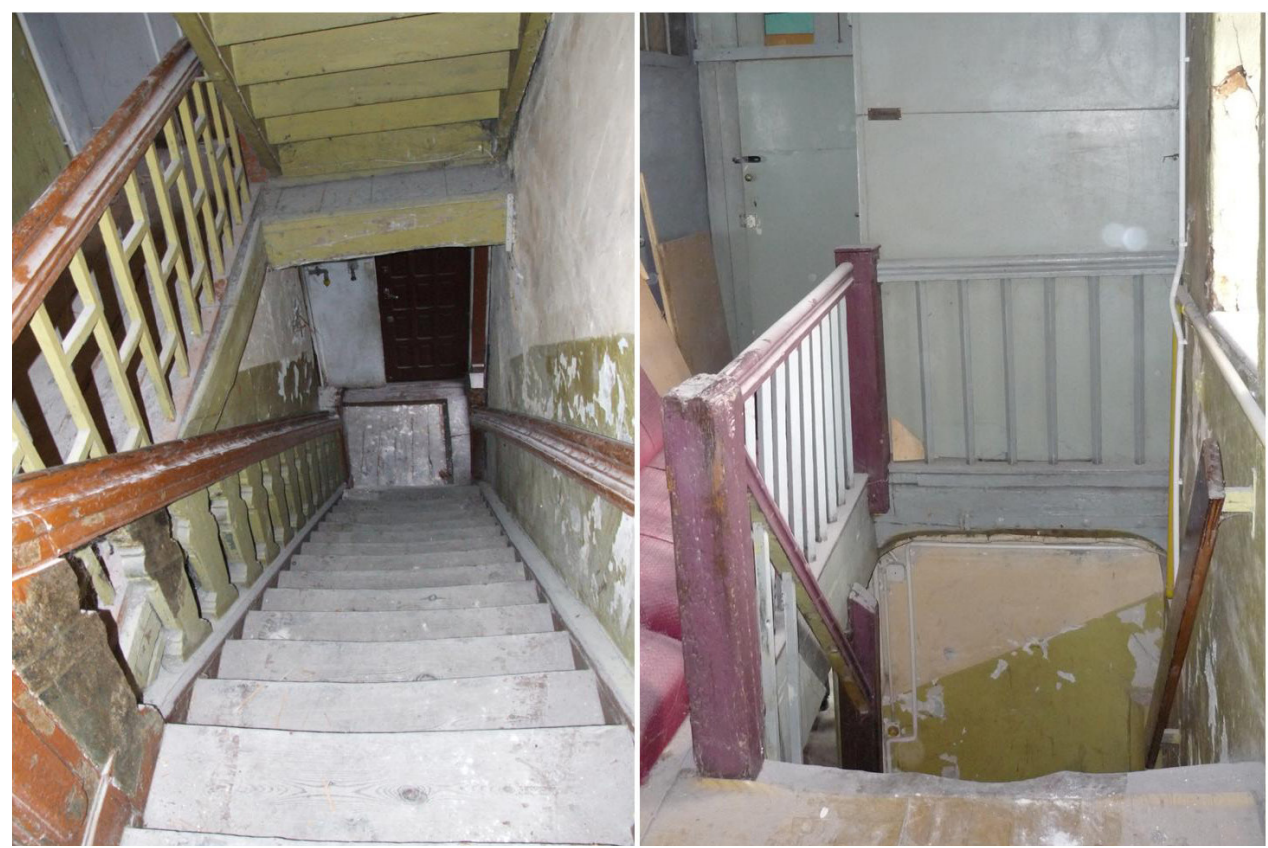

Il. 9 Toruń, Pałac Fengera, główna klatka schodowa w budynku frontowym. Odcinki schodów pochodzące z różnych etapów adaptacji na cele mieszkalne: odcinek z parteru na I piętro z balustradą brusową polichromowaną z 1742 roku; balustrada szczeblinowa, kratowa między I a II piętrem powstała w czasie adaptacji na kamienicę wielorodzinną po 1835 roku i odcinek schodów między II a III piętrem z balustradą szczeblinową pionową, fot. J. Kucharzewska 

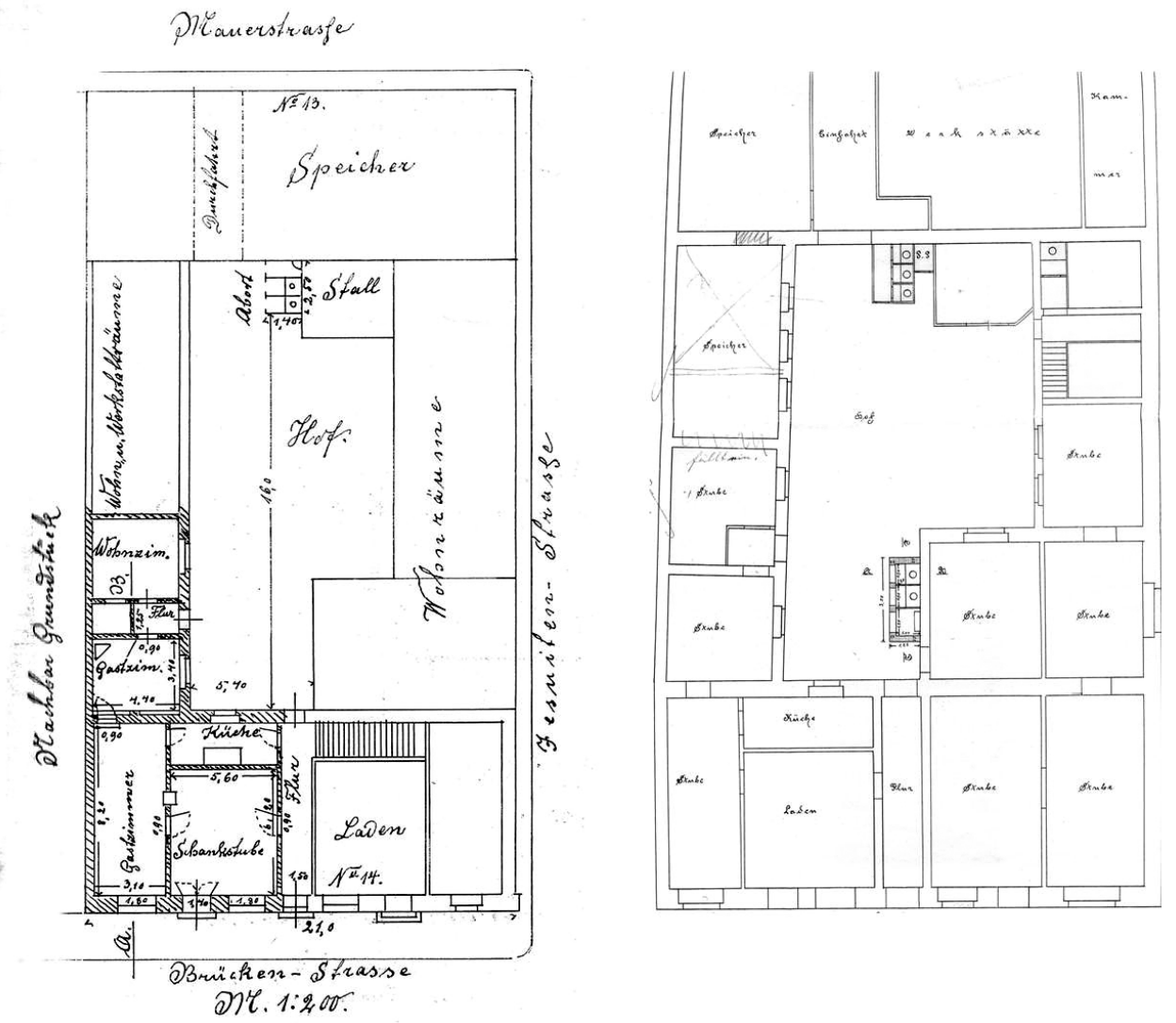

Il. 10 Toruń, Pałac Fengera, rzut parteru z 1897 i 1903 roku, Archiwum Państwowe w Toruniu, Akta miasta Torunia, sygn. G 2779, k. 60 i k. 121 